\title{
Целесообразность изучения микробиоценоза кишечника цыплят при инвазивно-бактериальном заболевании
}

Бовкун Г.Ф., кандидат ветеринарных наук, доцент

Овсеенко Ю.В., кандидат биологических наук, доцент

Рабченко Д.А., ветеринарный врач

ФГБОУ ВО «Брянский государственный аграрный университет»

\begin{abstract}
Аннотаиия: Патогенные эмерихии и эймерии оказывали септико-токсическое действие на организм цыплят при постоянстве обитания и колонизации кишечника эшерихиями сероварианта $\mathrm{O}_{2} \mathrm{C}$ последующим их проникновением и ииркулированием 6 крови. Соответствующие патологоанатомические изменения у больных иьплят были подтверждены результатами бактериологического исследования кроби, содержимого слепых кишок, соскобов слизистой толстого кишечника. Положительную динамику лечения обеспечили кокцидиостатик и антибактериальный препарат, к которому был чубствителен идентифицированньй бозбудитель колибактериоза: суточная смертность б зараженном стаде снизилась с 12,0\% (1-й день лечения) до 1,09\% (6-й день).
\end{abstract}

Ключебые слоба: иыллята-бройлеры, микробиоценоз кишечника, колибактериоз, эймериоз, динамика лечения, микробиологические исследования.

Введение. В промышленном птицеводстве в патологии молодняка и взрослых кур ведущее значение имеют смешанные вирусно-бактериальные, бактериальные, инвазивно-бактериальные заболевания. Течение этих болезней сопровождается разнообразными признаками, что затрудняет диагностику, обусловливает низкую эффективность лечебных мероприятий [1-3].

Анализируя научные сведения о кишечном иммунитете у птиц [4], сообщают о важности физических барьеров (муцина, $\mathrm{pH}$, секретах поджелудочной железы, перистальтике, аэробиозе), иммунных механизмах (М-клетки, NK-клетки, В-клетки, Т-клетки, лизоцим, фагоциты, антимикробные пептиды, продуцентами которых являются эпителиальные клетки, псевдоэозинофилы), тогда как роль микрофлоры кишечника ограничивается конкурен- цией за нутриенты, места прикрепления, продуцированием бактериофагов, бактерицинов, короткоцепочечных жирных кислот. По современным данным [5], центральная роль в формировании кишечного гомеостаза принадлежит облигатной микрофлоре и ее ведущим представителям - бифидобактериям.

Распространение гельминтозов и паразитарных заболеваний у птиц и сельскохозяйственных животных обусловливает поиск и применение новых кокцидиостатиков [3], затрудняет технологические приемы переработки помета [6].

Цель работы - установление этиологии заболевания на основании патологоанатомических изменений, бактериологического исследования крови, изучения структуры и количественных показателей микрофлоры кишечника, исключения паразитарной этиологии в соскобах слизистой кишечника, определения морфологических и биохимических показателей крови, чувствительности выделенной микрофлоры к антибактериальным препаратам.

Материал и методика исследования. Эвтаназию 50 больных цыплят-бройлеров 28-дневного возраста, имевших признаки диареи, обезвоживания, токсикоза, поражения нервной системы и полученных с объекта, где в течение нескольких дней отмечали падеж цыплят и низкую лечебную эффективность применения препаратов, проводили обескровливанием пункцией сердца. Для характеристики морфологических показателей использовали цитрированную кровь. Количество эритроцитов, лейкоцитов, гемоглобина, СОЭ определяли общепринятыми методами. В сыворотке крови спектрофотометрически определяли концентрацию обще- 
го белка. Количество мочевины определяли с помощью диагностикума Ольвекс на спектрофотометре Unico. В качестве значений физиологической нормы принимали интервалы соответствующих показателей, приведенные в справочнике [7].

После патологоанатомического обследования и оформления протокола кровь паренхиматозных органов сеяли на жидкие и плотные основные питательные среды, посевы культивировали 18 ч при $37^{\circ} \mathrm{C}$. В дальнейшем использовали схему выделения и идентификации эшерихий по методическим указаниям [8].

Роль микробной экологии при патологии органов пищеварения у цыплят изучали микробиологическим исследованием содержимого слепых кишок в соответствии с методическими рекомендациями [9].

Инкубировали посевы протеев, группы условно-патогенных энтеробактерий (УПЭ), ассоциаций гнилостных бацилл и стафилококков, энтерококков и эшерихий при $37-38^{\circ} \mathrm{C}$ в течение суток. Посевы лактобацилл, бифидобактерий выдерживали 2 суток, посевы грибков - 4 суток при температуре $37-38^{\circ} \mathrm{C}$.

Для обнаружения протеев, синегнойной палочки 1 мл разведения $10^{-3}$ содержимого слепых кишок сеяли на косяк ПА или МПА по Шукевичу, затем выросшие культуры оставляли при комнатной температуре, идентификацию проводили по культурально-морфологическим свойствам и фенилаланиндезаминазной активности.

Грибки выделяли на среде Сабуро посевом 0,1 мл разведения $10^{-3}$, втирая шпателем, подсчитывали бело-матовые выпуклые колонии, проводили бактериоскопию по Граму. Дифференцировали дрожжеподобные грибки бактериоскопией. Грам-поло- жительные почкующиеся, округлой формы бактерии - дрожжи, Грам-положительные крупные почкующиеся бактерии удлиненной формы - грибки из рода Candida.

Группу УПЭ выделяли посевом 0,1 мл разведений $10^{-4}$ на агар Симмонса, подсчитывали количество цитратредуцирующих колоний, идентификацию которых проводили при наличии пневмонии, перитонита у цыплят по биохимическим показателям.

Гемолитически активные ассоциации почвенных бацилл, стафилококков, кишечной палочки выделяли посевом на 5\% кровяной агар 0,1 мл разведений $10^{-4}$ в чашках Петри. Бактериоскопией по Граму изучали морфологические свойства микроорганизмов выделенных колоний, по которым их идентифицировали.

Анаэробные клостридии выделяли посевом 1 мл разведений $10^{-3}-10^{-5}$ на среду Вильсона-Блера в пробирках. Черные колонии характерны для Cl. perfringens, другие анаэробы образовывали зеленовато-черные, некоторые аэробы - черное окрашивание. Подсчитывали количество колоний.

Энтерококки, к которым относят Str. faecium, Str. faecalis, выделяли посевом 0,1 мл разведения $10^{-4}$ на сывороточно-теллуритовый агар, проводили учет черных колоний.

Эшерихии выделяли посевом 0,1 мл разведения 10-6 на агар Эндо, который готовили из концентрата, в чашках Петри. Подсчитывали типичные фиолетовые колонии, состоящие из толстых палочек среднего размера, а также розовые и бесцветные колонии, которые относят к слабо расщепляющим лактозу и лактозонегативным.

Молочнокислые бактерии и стрептококки выделяли посевом 1 мл разведения 10-7 на лактоа- гар, культивирование проводили в микроаэрофильных условиях. Подсчитывали мелкие и средние выпуклые, непрозрачные колонии, которые при бактериоскопии содержали Грам-положительные палочки разных размеров - одиночные или цепочкой, и кокки овальной формы - парами, цепочками.

Бифидобактерии выделяли посевом 1 мл разведения 10-9 на кукурузно-лактозную среду (КЛС) в пробирки. Перед посевом среду КЛС реактивировали, выдерживая на водяной бане 20 мин, затем резко охлаждали. Подсчитывали в толще столбика колонии, похожие на «гвоздики», «груши».

Полученные цифровые данные выражали в десятичных логарифмах КОЕ/г с использованием таблицы «Мантиссы десятичных логарифмов».

Для выявления положения микроорганизмов В структуре микробиоценоза толстого кишечника использовали показатель постоянства С (\%), который рассчитывали по формуле: $\mathrm{C}=(\mathrm{n} \mathrm{x}$ 100)/N, где $\mathrm{n}$ - число обследуемых цыплят, от которых выделен микроорганизм, N - общее число обследуемых цыплят.

Лабораторные исследования на эймериоз включали приготовление соскобов из пораженного участка кишечника, их фиксирование спиртом, окрашивание по Романовскому-Гимзе, микроскопирование. Шизонты характеризовали как образования овальной или круглой формы, внутри их множество мерозоитов; мерозоиты - клетки продолговатой формы с ядром; незрелые ооцисты - клетки с зернистой цитоплазмой шарообразной или яйцевидной формы.

Чувствительность к антибактериальным препаратам выделенной микрофлоры определяли по методическим указаниям [10]. 


\begin{tabular}{|c|c|c|c|c|}
\hline № & $\begin{array}{l}\text { Вид выделенных } \\
\text { культур }\end{array}$ & $\begin{array}{c}\text { \% } \\
\text { выделения }\end{array}$ & $\begin{array}{l}\text { Наличие } \\
\text { эймерий }\end{array}$ & $\begin{array}{c}\% \\
\text { выделения }\end{array}$ \\
\hline 1 & Streptococcus faecium & 2 & Нет & - \\
\hline 2 & E.coli $\mathrm{O}_{2}$ & 98 & $\begin{array}{c}\text { Ооцисты } \\
\text { и шизонты }\end{array}$ & 100 \\
\hline
\end{tabular}

\begin{tabular}{|c|c|c|c|c|}
\hline \multirow{3}{*}{ Микроорганизмы } & \multicolumn{4}{|c|}{ Нозологические формы } \\
\hline & \multicolumn{2}{|c|}{$\begin{array}{c}\text { Ассоциативное } \\
\text { течение колибактериоза } \\
\text { и эймериоза }\end{array}$} & \multicolumn{2}{|c|}{$\begin{array}{c}\text { Колибактериоз, } \\
\text { инвазия единичными } \\
\text { эймериями }\end{array}$} \\
\hline & Ig KOE/r & C & Ig KOE/r & C \\
\hline Протеи & 3 & 25 & 0 & 0 \\
\hline Грибы & 0 & 0 & 0 & 0 \\
\hline УПЭ & 0 & 0 & 0 & 0 \\
\hline Гемолитические E.coli & $6,84 \pm 0,46$ & 60 & 0 & 0 \\
\hline Фузобактерии & $5,49 \pm 0,12$ & 40 & 0 & 0 \\
\hline Энтерококки & $5,53 \pm 0,48$ & 100 & 0 & 0 \\
\hline Эшерихии & $7,50 \pm 0,28$ & 100 & $8,89 \pm 0,36$ & 100 \\
\hline $\begin{array}{l}\text { Лактозонегативные } \\
\text { эшерихии }\end{array}$ & $7,58 \pm 0,32$ & 100 & 0 & 0 \\
\hline Лактобациллы & 0 & 0 & 0 & 0 \\
\hline Бифидобактерии & 0 & 0 & 0 & 0 \\
\hline
\end{tabular}

\section{Результаты исследований} и их обсуждение. Патологоанатомических признаков вирусных респираторных заболеваний $\mathrm{y}$ обследуемых цыплят не обнаружили. У всех больных цыплят обнаружили гастроэнтероколит, у 98\% из них в слепой кишке было геморрагическое или катаральное воспаление. У всех больных также были признаки поражения печени (застойная гиперемия, разные виды дистрофии). У некоторых обследуемых цыплят (20\%) были четкие патологоанатомические признаки колибактериоза (гнойно-фибринозный перитонит, перикардит, пневмония). Остальные больные цыплята имели патологоанатомическую картину токсикоза с поражением поджелудочной железы, спленомегалией, миокардиодистрофией.

Больные цыплята имели тяжелые поражения нескольких органов, что обусловливало необходимость проведения бактериологического исследования крови и исключения эймериозной инвазии.

Из крови сердца одного цыпленка (2\%) выделили Str. faecalis, в соскобах слизистой кишечника не обнаружили ооцисты и шизонты эймерий, что свидетельствовало об энтерококкозе у $2 \%$ цыплят. Из крови остальных обследуемых, имевших разные патологоанатомические признаки, выделяли патогенную E.coli сероварианта $\mathrm{O}_{2}$ - возбудителя колибактериоза (табл. 1). Выделенные культуры эшерихий имели одинаковые биологические свойства: расщепляли лактозу, глюкозу, маннит, образовывали индол, в капельной РА с О коли-агглютинирующей сывороткой и кипяченой в течение 45 мин агаровой взвесью давали положительную реакцию, что свидетельствовало о циркулировании одной культуры возбудителя колибактериоза у обследованных цыплят.

Структуры эймерий (ооцисты, шизонты) обнаруживали так- же у 98\% цыплят только в слепой кишке, что свидетельствовало о принадлежности к виду $E$. tenella [11]. При геморрагическом воспалении обнаруживали умеренную плотность паразитов, при катаральном - единичные особи.

На основании бактериологических и микроскопических исследований установлено ассоциативное течение у бройлеров колибактериоза и эймериоза с тяжелыми токсикозом и поражениями внутренних органов. С целью установления способа заражения и очага концентрации и пролиферации возбудителя колибактериоза провели микробиологическое исследование содержимого слепых кишок больных цыплят (табл. 2).

Микробный пейзаж содержимого слепых кишок цыплят при ассоциативном течении колибактериоза и эймериоза был представлен 4 видами микроорганизмов: протеями при плотности 3 lg KOE/г, положение которых в структуре микробиоценоза больных цыплят (C=25\%) не подтверждало их постоянства обитания; фузобактериями, количество которых составляло

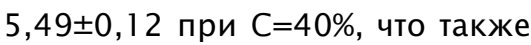
не подтверждало их постоянства при данной патологии. Постоянными представителями микробиоценоза слепых кишок при ассоциативном течение колибактериоза и эймериоза были энтерококки, плотность которых не превышала нормативных показателей, и эшерихии с гемолитической активностью и выраженными ферментативными свойствами, принадлежащие к сероварианту $\mathrm{O}_{2}$, суммарная плотность которых свидетельствовала о колонизации слизистой толстого кишечника, на фоне которой вегетировали также лактозонегативные особи, не выполняющие защитных функций и не принадлежащие к патогенным серовариантам. 


\begin{tabular}{|c|c|c|}
\hline \multirow[b]{2}{*}{ Показатели } & \multicolumn{2}{|c|}{ Нозологические формы } \\
\hline & $\begin{array}{c}\text { Ассоциативное течение } \\
\text { колибактериоза и эймериоза }\end{array}$ & $\begin{array}{l}\text { Колибактериоз, инвазия } \\
\text { единичными эймериями }\end{array}$ \\
\hline Эритроциты, $10^{12} / л$ & $1,59 \pm 0,41 *$ & $1,62 \pm 0,37$ \\
\hline Лейкоциты, $10^{9}$ /л & $22,3 \pm 1,3$ & $23,1 \pm 1,165$ \\
\hline Гемоглобин, г/л & $78 \pm 4,3 *$ & $88,33 \pm 4,18$ \\
\hline СОЭ, мм/час & $5,6 \pm 1,06$ & $4,3 \pm 1,16$ \\
\hline Гематокрит, \% & $25 \pm 1,45^{*}$ & $28,5 \pm 5,3^{*}$ \\
\hline Общий белок, г/л & $4,56 \pm 0,13$ & $4,27 \pm 0,17$ \\
\hline Мочевина, моль/л & $0,25 \pm 0,08$ & $0,15 \pm 0,01$ \\
\hline
\end{tabular}

Отличие от соответствующих референсных значений достоверно при * $\mathrm{P} \leq 0,05$.

у больных колибактериозом цыплят на фоне поражения слепых кишок единичными эймериями обнаружили абсолютную колонизацию слизистой патогенными эшерихиями сероварианта $\mathrm{O}_{2}$, плотность которых составляла

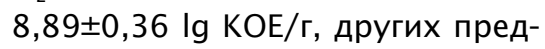
ставителей факультативной и индигенной микрофлоры не выделяли.

Ведущих представителей индигенной микрофлоры - лактобацилл и бифидобактерий - при установленных нозологических формах не обнаруживали, что усугубляло тяжесть заболевания.

Для установления патогенеза ассоциативного течения колибактериоза, эймериоза и энтерококкоза представляло интерес изучение морфологических и биохимических показателей крови (табл. 3).

Статистически достоверное угнетение гемопоэза, количества гемоглобина и эритроцитов отмечали у цыплят при ассоциативном колибактериозе и эймериозе. Показатели количества эритроцитов, лейкоцитов, гемоглобина у больных колибактериозом и слабой инвазией эймериями были в нормативных пределах. У всех больных цыплят отмечали резкое падение гематокрита, подтверждающее дефицит форменных элементов крови и угнетение функционирования костного мозга токсинами возбудителей.
Количество общего белка в крови больных цыплят соответствовало нормативным показателям, что на фоне септической инфекции свидетельствовало о слабой секреции иммуноглобулинов. Показатели мочевины в крови также соответствовали нормативным, что исключало повреждение почек токсинами возбудителей.

Культуры №1 E.coli-O 2 , выделенные из крови, и культуры №2 E.coli-O ${ }_{2}$, выделенные из кишечника, были устойчивы к тетрациклину, гентамицину, колистину, флорфениколу, левомицетину, амоксициллину, фурадонину, что свидетельствовало об их полной идентичности. Испытуемые культуры были чувствительны к хинолоновым препаратам трех поколений (табл. 4), поэтому для лечения мы рекомендовали препарат энрофлон для орального применения.

Для профилактики и лечения цыплят объекта, где диагностиро- вали ассоциативное течение колибактериоза и эймериоза, применяли Монимакс, который характеризуется высокой стабильностью в кормах и гомогенностью, выпаивали Энрофлон в лечебных дозах.

Рекомендуемые препараты обеспечили положительную динамику лечения больных цыплят. В первый день применения погибло 4800 голов, что составляло $12 \%$ поголовья, выращиваемого на объекте (табл. 5). В последующие дни лечения смертность сокращалась, и в конце лечения составила 1,09\%. Всего за период болезни погибло 27,2\% цыплят, и сохранность к убою составила 71,6\%.

Заключение. Установленные патологоанатомические изменения у больных цыплят соответствовали септико-токсическому и инвазивному воздействию патогенных эшерихий и эймерий, что подтверждали результаты бактериологического исследования крови, содержимого слепых ки-

\begin{tabular}{|c|c|c|c|}
\hline Культуры & Ципрофлоксацин & Офлоксацин & Энрофлоксацин \\
\hline E.coli № 1 & Чувствительна & Чувствительна & Чувствительна \\
\hline E.coli №2 & Чувствительна & Чувствительна & Чувствительна \\
\hline
\end{tabular}

Таблица 5. Результаты лечения цыплят на объекте, где выявлены заболевания

\begin{tabular}{lcccccc}
\hline Дни лечения & $\mathbf{1}$ & $\mathbf{2}$ & $\mathbf{3}$ & $\mathbf{4}$ & $\mathbf{5}$ & $\mathbf{6}$ \\
\hline Гибель цыплят, \% & 12,0 & 10,5 & 4,5 & 3,3 & 3,13 & 1,09 \\
\hline
\end{tabular}


шок, соскобов слизистой толстого кишечника.

Изучением микробиоценоза кишечника цыплят на фоне септико-токсического и инвазивного воздействия установлены постоянство обитания и колонизация слизистой кишечника патогенными эшерихиями сероварианта $\mathrm{O}_{2}$ с последующим проникновением и циркулированием в крови, при угнетении индигенной бифидо-, лактофлоры, снижением ферментативной активности полезных эшерихий и трансформацией их в условно патогенные.

Не все выделенные культуры патогенных эшерихий обладали гемолитической активностью, но имели идентичную чувствительность к хинолоновым препаратам и резистентность к ведущим антибиотикам.

Морфологические и биохимические показатели крови больных цыплят свидетельствовали о токсическом происхождении угнетения функционирования костного мозга при сохранении функции почек.

Рекомендуемые препараты Монимакс и Энрофлон обеспечивали положительную динамику лече- ния больных цыплят, сокращение смертности до 1,09\%.

\section{Литература}

1. Борисенкова А.Н. Проблемы бактериальных болезней птиц на современном этапе развития промышленного птицеводства // Болезни птиц в промышленном птицеводстве: Мат. науч.-практ. конф. - СПб., 2007. С. 198-202.

2. Ниязов Ф.А., Давлатов Р.Б., Дурдиев Ш.К. Особенности ассоциированного течения эймериоза и колибактериоза птиц // Болезни птиц в промышленном птицеводстве: Мат. науч.-практ. конф. - СПб., 2007. - С. 324-326.

3. Смоленский В.И., Киселев А.Л., Титова Т.Г. Научный подход к профилактике кокцидиоза птиц // Птицеводство. - 2018. - №1. - С. 50-52.

4. Фисинин В.И., Сурай П. Кишечный иммунитет у птиц: факты и размышления // С.-х. биология. - 2013. - №4. C. 3-25.

5. Бухарин О.В., Иванова Е.В., Перунова Н.Б. Регуляция иммунного гомеостаза кишечника человека метаболитами бифидобактерий в условиях микробного распознавания// Микробиология. - 2017. - №3. - С. 12-18.

6. Просянников Е.В., Попкович Л.В., Бовкун Г.Ф. Материало-сберегающие технологические приемы вермикомпостирования // Агро XXI. - 2009. №4-6. - С. 28-31.

7. Бессарабов Б.Ф., Клетикова Л.В., Алексеева С.А., Сушкова Н.К. Клинические и лабораторные методы исследования сельскохозяйственной птицы при незаразных болезнях. - М.: ЗооВетКнига, 2015. - 310 с.

8. Методические указания по лабораторной диагностике колибактериоза животных. - М., 2002. - 64 с.

9. Малик Н.И., Малик Е.В., Бовкун Г.Ф. Методические рекомендации по лабораторной диагностике кишечника молодняка сельскохозяйственных животных. - М., 2008. - 73 с.

10. Методы контроля. Биологические и микробиологические факторы. Определение чувствительности микроорганизмов к антибактериальным препаратам. - М., 2004. - 69 с.

11. Бессарабов Б.Ф., Мельникова И.И., Сушкова Н.С. Болезни птиц: уч. пособие. - СПб: Лань, 2009. - 448 с.

\section{Для контакта с авторами:}

Бовкун Галина Федоровна

E-mail: ter.1917Nin@yandex.ru

Овсеенко Юрий Валентинович

E-mail: yura.ovceenko@mail.ru

Рабченко Дарья Алексеевна

E-mail: dr89611080014@gmail.com

\title{
The Effectiveness of the Screening of Intestinal Microbiota for Diagnostics and Treatment of an Associated Invasive and Bacterial Disease in Broilers
}

\author{
Bovkun G.F., Ovseenko Y.V., Rabchenko D.A. \\ Bryansk State Agrarian University
}

\begin{abstract}
Summary: A disease circulating in a broiler farm was found to be a result of the combined septic and toxic effects of pathogenic Escherichia and Eimeria strains. Escherichia (serovar $O^{2}$ ) appeared a constant habitant of the intestines and inhibitor of beneficial indigenous species (Lactobacilli, Bifidobacteria); subsequently it entered the bloodstream with resulting hemotoxic effects. The pathological changes in broilers revealed by the post mortem examination and biochemical blood analysis were in accordance with the results of microbiological studies of blood, cecal chymus, and scrapes of the mucosa of the large intestine. The treatment with a coccidiostatic (against Eimeria identified as E. tenella) and antibiotic (experimentally found effective against the pathogenic Escherichia) provided positive dynamics in the infected flock: daily mortality rate in broilers decreased from $12.0 \%$ (day 1 of the treatment) to $1.09 \%$ (day 6).
\end{abstract}

Keywords: roiler chicks, intestinal microbiota, colibacteriosis, eimeriosis, dynamics of treatment, microbiological studies. 